\title{
ANALYSIS OF RICE DISTRIBUTION CHANNEL IN NGAWI REGENCY, EAST JAVA PROVINCE OF INDONESIA
}

\author{
Retnoningsih Dwi \\ Department of Agricultural Socio-Economics, University of Brawijaya, Indonesia \\ *E-mail: dwiretnoningsih@ub.ac.id
}

\begin{abstract}
Food production is an important factor in food security. Government efforts to achieve rice self-sufficiency continue to be carried out so that community needs can be fulfilled without having to import. Strengthening the distribution channel for rice production can be a solution to food security. This research aims to analyze the rice distribution channel efficiency in Ngawi Regency, East Java. In determining the rice distribution channel efficiency, marketing margins, share of margins, share of costs, and share of profits were analyzed. The research results show that there are nine channels in Ngawi Regency in which six channels of channels I, II, V, VI, VIII, and IX are efficient, while channels II, IV and VII are not yet efficient. It implies the need for policies that can provide reasonable profits for each party to support more efficient rice distribution channels.
\end{abstract}

\section{KEY WORDS}

Margins, share, costs, profits, efficiency, channels.

The availability of food in sufficient quantity at affordable prices is one of the main objectives of national agricultural development (Yosefanny et al. 2017), especially rice availability. Rice is the main staple food for Indonesian people. The increased population of Indonesia from year to year results in insufficient rice supply. Sugianto (2006) states that rice consumption in Indonesia is higher than rice production. It influences social and economic stability. An increased rice production program can act as a solution to deal with these problems. In addition, the distribution aspect and affordable prices are components need to be considered to facilitate people's access to food. To improve public accessibility to rice, it is necessary to apply the supply chain management concept to meet people's needs for rice supply in an effective and efficient manner.

The weak economic competitiveness of rice in Indonesia is caused by weak economic institutions, especially supply chain. Supply chain was first introduced in the early 1980s (Nee, 2008). Regional institutional system is still shackled by centralized development policy, causing undeveloped people's creativity and weak social capital. Therefore, reforms within the regional autonomy framework should provide opportunities and trust to regional institutions to improve resource management efficiency. Agricultural supply chain in Indonesia involves many actors, from farmers to consumers. However, due to the lack of a direct collective system of small farmers, many actors and transactions must be passed first. This eventually resulted in high prices of agricultural products. The above problems arise because of the lack of coordination in product collection between producers and market players. High logistics costs are a challenge in the supply chain process. It is due to the long chain process from small farmers to market players. At present, many retailers become the power holder in the supply chain. Thus, it needs cooperation from various parties to overcome the high logistics costs in Indonesia, both from the government and business actors. According to Sharma et al. (2014), overcoming supply chain inefficiency can be conducted by redesigning procurement, distribution, intermediary's collaboration, and logistics system.

Many researchers have conducted research on rice supply chains in Indonesia. Garside and Asjari (2015) found that, in general, the rice supply chain network in Indonesia starts from farmers as rice cultivators who sell dry unhusked rice to middlemen. Then, middlemen sell dry unhusked rice to the rice milling unit to be dried and grounded into rice. 
Finally, rice is sold back to consumers. The research results of (South, Sumarauw, and Karuntu 2017) showed that the rice farmers get relatively small profits from the rice supply chain. It is due to different time and costs in rice cultivation activities. The longer the time the farmers take, the higher the costs incurred. Meanwhile, traders only need around one week to sell rice to retailers or consumers. However, some of the literature describes descriptively. This research attempts to analyze the rice distribution efficiency by using several analytical tools including marketing margins, share of costs, share of margins, and share of profits. Data from the analysis results will show the efficiency level in each rice marketing channel.

\section{LITERATURE REVIEW}

Supply chain management is a unified marketing system that includes integration between actors so as to provide satisfaction to customers. The implementation of supply chain management includes the introduction of supply chain members and with whom he relates, what processes are carried out on each relationship between the actors of the supply chain. The aim is to win competition and profits for the company and all members, including the final consumer. The supply chain system is a dynamic and complex system (Eldabi \& Keramati, 2011).

The marketing system is an important part of the chain of goods from production to consumers. The marketing system also determines the market efficiency of an item trading system, including food. In this agribusiness system, post-harvest rice is one of the subsystems covering activities ranging from harvest to producing rice and by products. Poor handling of post-harvest rice will result in the minimum yield of rice produced, this will have an impact not only on farmers, but also all institutions related to rice. Supply chain is a sequence of scenes (activities and actors) from upstream sourcing and downstream and vice versa. In the supply chain there are three streams that must be managed, namely the flow of products, the flow of money and information. Supply chain management involves various parties from inside and outside the company.

\section{METHODS OF RESEARCH}

This research was conducted in Ngawi Regency using purposive sampling (intentionally) with the consideration that Ngawi Regency was one of the regencies achieving the national-level rice production improvement award in 2018. In addition, according to (Mardianto, Supriyatna, and Agustin 2016), the rice supply chain in Ngawi Regency is relatively diverse compared to other regencies in East Java. It might be caused by the fact that Ngawi Regency is directly adjacent to Central Java, causing a wider rice marketing.

Purposive sampling was used to determine the respondents in this research. Farmers and unhusked rice/rice marketing agencies in Ngawi Regency became the respondents. Thus, the respondents were farmers, middlemen/collectors, wholesalers, retailers, and consumers. Farmers included the landowners and the rice farmers of 40 respondents. Collectors/middlemen comprised 3 respondents each. Wholesalers comprised 2 respondents and consumers comprised 15 respondents.

There were two types of data used in this research. The first type was Primary data obtained based on field survey results at farmer groups, farmers, traders, and consumers using a questionnaire. The second type was Secondary data obtained from related agencies or institutions. Secondary data were obtained from several related agencies such as:

- Department of Trade at the Regency level to obtain data on price at the consumer level and traders/wholesalers/distributors engaged in the unhusked rice/rice commodity;

- BULOG (The Indonesia Logistics Bureau) office of the sub regional division to obtain Government Purchasing Price, merchant partners, and rice policies;

- Department of Agriculture to obtain data on prices at the producer level and data of farmers/farmer groups. 
In determining the rice distribution channel efficiency in Ngawi Regency, several analytical tools including marketing margins, share of costs, share of margins, and share of profits were used. The data results show the efficiency level in each rice marketing channel.

To determine the marketing margins, distribution, shares, and profits of the involved marketing agencies to the total margin of various marketing channels, the marketing margin analysis was used (Masyrofie 1994). The marketing efficiency theory used as a reference is the theory proposed by (Tomek Wg and Robinson Kl. 1990) which defines marketing margin as the difference between the price paid by consumers and that obtained by producers. Marketing margin can be calculated using the following formula:

$$
M P=P_{r}-P_{f}
$$

For one trader level, marketing margin can be calculated using the following formula:

$$
M P=K P+B P
$$

Where: $M P=$ Marketing Margin; $P_{r}=$ Price at the consumer level taken from the average price; $P_{f}=$ Price at the producer level taken from the average selling price; $K P=$ Marketing Profits; $\mathrm{BP}=$ Marketing Costs; $\mathrm{KP}=\mathrm{MP}-\mathrm{BP} ; \mathrm{BP}=\mathrm{MP}-\mathrm{KP}$.

Share of margins can be calculated using the following formula:

$$
\mathrm{Sm}=\frac{M i}{M \text { total }} \times 100 \%
$$

Where: $\mathrm{Mi}=$ Margin in the $\mathrm{i}^{\text {th }}$ agency; $\mathrm{M}$ total $=$ Total margin in all marketing agencies .

Share of prices received by farmers can be calculated using the following formula:

$$
\mathrm{Sf}=\frac{P f}{P r} \times 100 \%
$$

Where: $\mathrm{Sf}=$ Share of prices received by farmers; $\mathrm{Pf}=$ Price at the farmer level; $\mathrm{Pr}=\mathrm{Price}$ at the retailer level; Indicators of marketing efficiency can be measured by the following criteria:

- If share of prices is higher than share of marketing margins, the marketing channel is categorized as efficient;

- If share of prices is smaller than share of marketing margins, the marketing channel is categorized as inefficient.

Share of costs of the $\mathrm{i}^{\text {th }}$ marketing agency can be calculated with:

$$
\mathrm{Sbi}=\frac{B i}{B \text { total }} \times 100 \%
$$

Where: Sbi $=$ Share of costs of the $\mathrm{i}^{\text {th }}$ marketing agency; $\mathrm{Bi}=$ Cost type; $\mathrm{B}$ total $=$ Total costs of all marketing agencies.

Share of profits of the $\mathrm{i}^{\text {th }}$ marketing agency can be calculated with:

$$
\mathrm{Ski}=\frac{K i}{K \text { total }} \times 100 \%
$$

Where: Ski $=$ Share of profits of the $\mathrm{i}^{\text {th }}$ marketing agency; $\mathrm{Ki}=$ Profits of the $\mathrm{i}^{\text {th }}$ marketing agency; $\mathrm{K}$ total $=$ Total profits.

The $\pi / C$ Ratio analysis was used to identify the real distribution of profits accepted by each agency. The $\pi / C$ Ratio for producers can be calculated using the following formula:

$$
\pi / C_{\text {Ratio }} \text { producer }=\frac{\text { Selling Price }}{\text { Total Costs }}
$$

Where: Selling Price $=$ Product selling price by producers to traders; Total costs $=$ Total production costs by producers. 
The $\pi / C$ Ratio for traders can be calculated using the following formula:

$$
\pi / \mathrm{C}_{\text {Ratio }} \text { trader }=\frac{\pi(\mathrm{i})}{\text { Total Costs }(i)}
$$

Where: $\pi(\mathrm{i})=$ Profits received by the $\mathrm{i}^{\text {th }}$ trader; Total costs $(\mathrm{i})=$ Total marketing costs by the $\mathrm{i}^{\text {th }}$ trader.

If the comparison between share of profits and marketing costs of each marketing agency involved in the marketing process is equitable and quite logical, the marketing system is considered efficient.

\section{RESULTS AND DISCUSSION}

The marketing margin analysis was used in determining the efficiency level of distribution channels to obtain share of profits and share of costs in each agency involved. By knowing the distribution of each agency's shares, we can determine the efficiency level of the existing distribution channels. Different distribution channels result in the different total margin at each distribution channel. Additionally, supply chain effectiveness can be analyzed through the results of the $\pi / C$ Ratio which present profits for each cost incurred. The $\pi / C$ Ratio analysis was used to identify the real distribution of profits acceptance by each agency. If the results of the $\pi / C$ Ratio show a real distribution, the channel is considered efficient. Margin calculation is obtained from the difference between the selling price of $\mathrm{P} 1$ and producers, and so on. From the research results on rice distribution channels in Ngawi Regency, nine channels are obtained.

In Channel I of the unhusked rice distribution, the highest share of prices is in producers/farmers of $69.9 \%$. It is because the farmers incur the highest farming costs to produce unhusked rice/rice compared to P1 (farmers' group's association), P2 (RMU), P3 (wholesalers), and P4 (retailers). Share of costs incurred by producers/farmers is $69.94 \%$. When compared between P1, P2, P3, and P4, the highest share of prices and share of margins are in P2 (RMU). Share of margins and share of costs in P2 are $20.7 \%$ and $18.4 \%$, respectively. The high share of margins and share of costs is in P2 because P2 (RMU) incurs the highest costs in processing unhusked rice into rice compared to traders who only sell without processing. Based on share of prices and share of costs, Channel I is considered efficient.

Table 1 - Calculation of Shares of Unhusked Rice/Rice in Channel I

\begin{tabular}{|c|c|c|c|c|c|c|c|c|c|}
\hline \multirow{2}{*}{ Subject } & \multirow{2}{*}{ Price } & \multirow{2}{*}{ Margin } & \multirow{2}{*}{ Cost } & \multirow{2}{*}{ Profit } & \multicolumn{4}{|c|}{ Share } & \multirow{2}{*}{ т/C Ratio } \\
\hline & & & & & Price (\%) & Margin (\%) & Cost (\%) & Profit (\%) & \\
\hline Producer & 4,600 & 400 & 2,164 & 2,436 & 35.9 & 4.9 & 69.9 & 6.3 & 2.1 \\
\hline P1 & 5,000 & 3,800 & 20 & 4,980 & 3.1 & 46.3 & 0.6 & 12.9 & 249.0 \\
\hline P2 & 8,800 & 1,700 & 570 & 8,230 & 29.7 & 20.7 & 18.4 & 26.8 & 14.4 \\
\hline P3 & 10,500 & 2,300 & 160 & 10,340 & 13.3 & 28.0 & 5.2 & 32.7 & 64.6 \\
\hline P4 & 12,800 & - & 180 & 12,620 & 18.0 & - & 5.8 & - & 70.1 \\
\hline
\end{tabular}

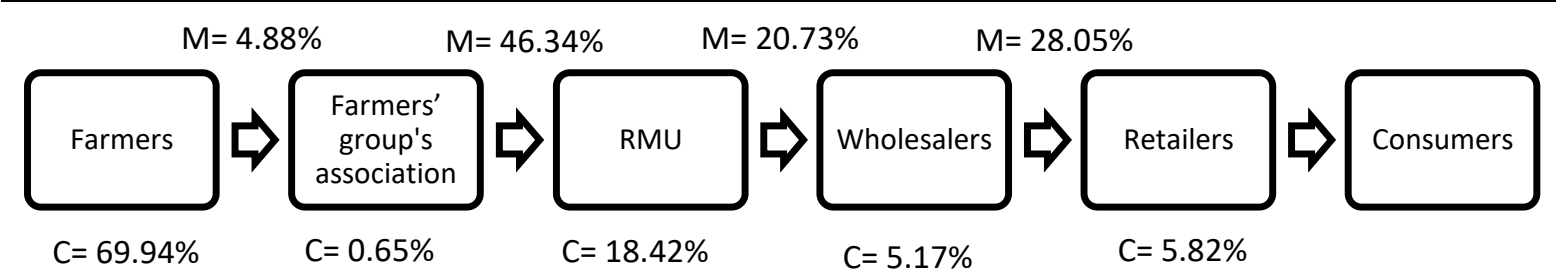

Where: $C=$ Share of costs; $M=$ Share of margins.

Figure 1 - Share of Margins and Share of Costs of Unhusked Rice in Channel I

Even though the highest share of prices, share of margins, and share of costs are in P1 and P2, the highest share of profits is in P3 (wholesalers) of $32.7 \%$. It is because wholesalers have a small cost and sell rice in large quantities. Furthermore, the highest $\pi / C$ 
Ratio is in P1/Farmers' group's association because P1 incurs the least share of costs. The $\pi / C$ Ratio of P1 is 249, meaning every IDR 1,- incurred by P1 will gain a profit of 249.

Figure 1 shows the rice distribution channel in the distribution channel I. Channel I starts from P (Farmers) - P1 (farmers' group's association) - P2 (RMU) - P3 (wholesalers) P4 (retailers) - Consumers. Farmers as producers sell unhusked rice to farmers' group's association, then farmers' group's association sell unhusked rice to RMU. RMU processes unhusked rice into rice to be sold to wholesalers. Wholesalers sell rice in the form of large packages to retailers. Finally, retailers sell retail rice at a more expensive price.

In Channel I of the unhusked rice distribution, the highest share of prices is in producers/farmers of $69.9 \%$. It is because the farmers incur the highest farming costs to produce unhusked rice/rice compared to P1 (farmers' group's association), P2 (RMU), P3 (wholesalers), and P4 (retailers). Share of costs incurred by producers/farmers is $69.94 \%$. When compared between P1, P2, P3, and P4, the highest share of prices and share of margins are in P2 (RMU). Share of margins and share of costs in P2 are $20.7 \%$ and $18.4 \%$, respectively. The high share of margins and share of costs is in P2 because P2 (RMU) incurs the highest costs in processing unhusked rice into rice compared to traders who only sell without processing. Based on share of prices and share of costs, Channel I is considered efficient.

Table 2 - Calculation of Shares of Unhusked Rice/Rice in Channel II

\begin{tabular}{|c|c|c|c|c|c|c|c|c|c|}
\hline \multirow{2}{*}{ Subject } & \multirow{2}{*}{ Price } & \multirow{2}{*}{ Margin } & \multirow{2}{*}{ Cost } & \multirow{2}{*}{ Profit } & \multicolumn{4}{|c|}{ Share } & \multirow{2}{*}{$\pi / C$ Ratio } \\
\hline & & & & & Price (\%) & Margin (\%) & Cost (\%) & Profit (\%) & \\
\hline Producer & 4,400 & & 2,164 & 2,236 & 34.4 & & 67.7 & 5.9 & 2.0 \\
\hline P1 & 4,800 & 400 & 120 & 4,680 & 3.1 & 4.8 & 3.8 & 12.3 & 39.0 \\
\hline P2 & 8,600 & 3,800 & 570 & 8,030 & 29.7 & 45.2 & 17.8 & 21.2 & 14.1 \\
\hline P3 & 10,500 & 1,900 & 160 & 10,340 & 14.8 & 22.6 & 5.0 & 27.3 & 64.6 \\
\hline P4 & 12,800 & 2,300 & 180 & 12,620 & 18.0 & 27.4 & 5.6 & 33.3 & 70.1 \\
\hline
\end{tabular}

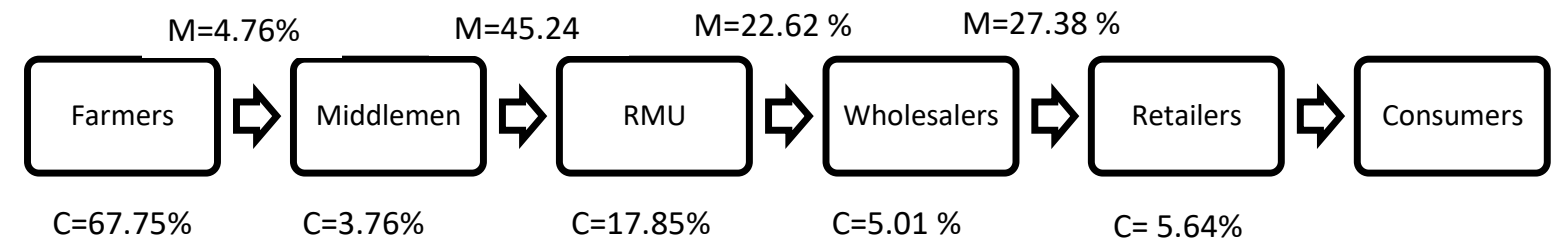

Where: $C=$ Share of costs; $M=$ Share of margins.

Figure 2 - Share of Margins and Share of Costs of Unhusked Rice in Channel II

Table 3 - Calculation of Shares of Unhusked Rice/Rice in Channel III

\begin{tabular}{|c|c|c|c|c|c|c|c|c|c|}
\hline \multirow{2}{*}{ Subject } & \multirow{2}{*}{ Price } & \multirow{2}{*}{ Margin } & \multirow{2}{*}{ Cost } & \multirow{2}{*}{ Profit } & \multicolumn{4}{|c|}{ Share } & \multirow{2}{*}{ т/C Ratio } \\
\hline & & & & & Price (\%) & Margin (\%) & Cost (\%) & Profit (\%) & \\
\hline Producer & 4,600 & & 2,164 & 2,436 & 35.9 & & 67.7 & 6.6 & 2.1 \\
\hline P1 & 4,800 & 200 & 120 & 4,680 & 1.6 & 2.4 & 3.8 & 12.6 & 39.0 \\
\hline $\mathrm{P} 2$ & 7,500 & 2,700 & 570 & 6,930 & 21.1 & 32.9 & 17.8 & 18.7 & 12.2 \\
\hline P3 & 10,500 & 3,000 & 160 & 10,340 & 23.4 & 36.6 & 5.0 & 27.9 & 64.6 \\
\hline P4 & 12,800 & 2,300 & 180 & 12,620 & 18.0 & 28.0 & 5.6 & 34.1 & 70.1 \\
\hline
\end{tabular}

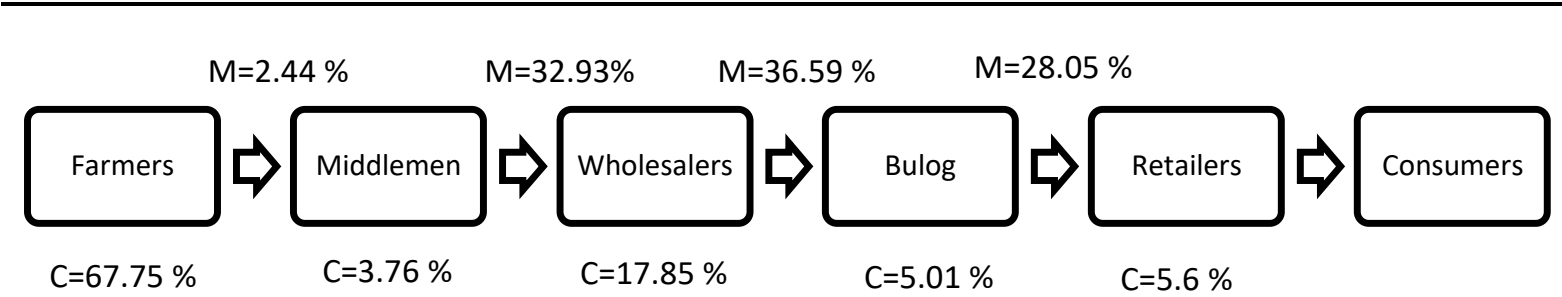

Where: $C=$ Share of costs; $M=$ Share of margins.

Figure 3 - Share of Margins and Share of Costs of Unhusked Rice in Channel III 
Even though the highest share of prices, share of margins, and share of costs are in P1 and P2, the highest share of profits is in P3 (wholesalers) of $32.7 \%$. It is because wholesalers have a small cost and sell rice in large quantities. Furthermore, the highest $\pi / \mathrm{C}$ Ratio is in P1/Farmers' group's association because P1 incurs the least share of costs. The $\pi / C$ Ratio of $P 1$ is 249, meaning every IDR 1,- incurred by P1 will gain a profit of 249.

Even though the highest share of prices, share of margins, and share of costs are in P3, the highest share of profits is in P4 (Retailers) of $34.1 \%$. P4 gains the highest profits because retailers have a small cost, the possibility to sell rice with a long shelf-life, and smaller rice packages sold compared to wholesalers. Furthermore, the highest $\pi / C$ ratio is in P4 (retailer) of 70.1, meaning every IDR 1,- incurred by P4 will gain a profit of 70.1.

In Channel IV of the unhusked rice/rice distribution, the highest share of prices is in producers/farmers of $32.8 \%$. It is because farmers incur the highest farming costs to produce unhusked rice/rice compared to P1 (farmers' group's association), P2 (middlemen), P3 (RMU), P4 (wholesalers), and P5 (retailers). Share of costs incurred by producers/farmers is $67.7 \%$. When compared between $\mathrm{P} 1, \mathrm{P} 2, \mathrm{P} 3$, and $\mathrm{P} 4$, the highest share of prices and share of margins are in P2 (wholesalers) of $40.7 \%$ with a very low cost of $2.5 \%$, causing wholesalers to gain the highest profits. It indicates the uneven distribution of share of margins and share of costs, resulting in inefficient rice distribution channels in channel I.

Table 4 - Calculation of Shares of Unhusked Rice/Rice in Channel IV

\begin{tabular}{cccccccccc}
\hline \multirow{2}{*}{ Subject } & \multirow{2}{*}{ Price } & \multirow{2}{*}{ Margin } & \multirow{2}{*}{ Cost } & \multirow{2}{*}{ Profit } & \multicolumn{4}{c}{ Share } & \multirow{2}{*}{ T/C Ratio } \\
\cline { 7 - 9 } & & & & & Price (\%) & Margin (\%) & Cost (\%) & Profit (\%) & \\
\hline Producer & 4,200 & & 2,164 & 2,036 & 32.8 & & 67.7 & 4.5 & 1.9 \\
P1 & 4,800 & 600 & 120 & 4,680 & 4.7 & 7.0 & 3.8 & 10.3 & 39.0 \\
P2 & 7,500 & 2,700 & 570 & 6,930 & 21.1 & 31.4 & 17.8 & 15.2 & 12.2 \\
P3 & 8,000 & 500 & 80 & 7,920 & 3.9 & 5.8 & 2.5 & 17.4 & 99.0 \\
P4 & 11,500 & 3,500 & 80 & 11,420 & 27.3 & 40.7 & 2.5 & 25.0 & 142.8 \\
P5 & 12,800 & 1,300 & 180 & 12,620 & 10.2 & 15.1 & 5.6 & 27.7 & 70.1 \\
\hline
\end{tabular}

Farmers

Where: $C=$ Share of costs; $M=$ Share of margins.

Figure 4 - Share of Margins and Share of Costs of Unhusked Rice in Channel IV

Table 5 - Calculation of Shares of Unhusked Rice/Rice in Channel V

\begin{tabular}{|c|c|c|c|c|c|c|c|c|c|}
\hline \multirow{2}{*}{ Subject } & \multirow{2}{*}{ Price } & \multirow{2}{*}{ Margin } & \multirow{2}{*}{ Cost } & \multirow{2}{*}{ Profit } & \multicolumn{4}{|c|}{ Share } & \multirow{2}{*}{$\pi / C$ Ratio } \\
\hline & & & & & Price (\%) & Margin (\%) & Cost (\%) & Profit (\%) & \\
\hline Producer & 4,200 & & 2,164 & 2,036 & 32.8 & & 67.3 & 4.4 & 1.9 \\
\hline $\mathrm{P} 1$ & 4,700 & 500 & 120 & 4,580 & 3.9 & 5.8 & 3.7 & 9.9 & 38.2 \\
\hline P2 & 8,500 & 3,800 & 570 & 7,930 & 29.7 & 44.2 & 17.7 & 17.1 & 13.9 \\
\hline P3 & 9,500 & 1,000 & 160 & 9,340 & 7.8 & 11.6 & 5.0 & 20.1 & 58.4 \\
\hline P4 & 10,000 & 500 & 20 & 9,980 & 3.9 & 5.8 & 0.6 & 21.5 & 499.0 \\
\hline P5 & 12,800 & 2.800 & 180 & 12,620 & 21.9 & 32.6 & 5.6 & 27.1 & 70.1 \\
\hline
\end{tabular}

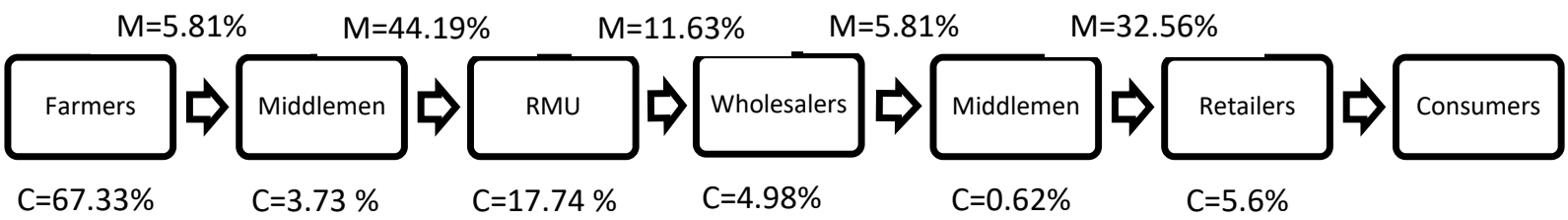

Where: $C=$ Share of costs; $M=$ Share of margins.

Figure 5 - Share of Margins and Share of Costs of Unhusked Rice in Channel V 
Furthermore, the highest $\pi / C$ ratio is also in $\mathrm{P} 4$ because $\mathrm{P} 4$ incurs the least share of costs. The $\pi / C$ Ratio of P4 is 142.8 , meaning every IDR 1,- incurred by P4 will gain a profit of 142.8.

In Channel $\mathrm{V}$ of the unhusked rice/rice distribution, the highest share of prices is in producers/farmers of $32.8 \%$. It is because the farmers incur the highest farming costs to produce unhusked rice/rice compared to P1 (middleman1), P2 (RMU), P3 (wholesalers), P4 (middleman2), and P5 (retailers). Share of costs incurred by producers/farmers is $67.3 \%$. When compared between $\mathrm{P} 1, \mathrm{P} 2, \mathrm{P} 3, \mathrm{P} 4$, and $\mathrm{P} 5$, the highest share of prices and share of margins are in P2 (RMU). Share of margins and share of costs in P2 are $44 \%$ and $17.74 \%$, respectively. The high share of margins and share of costs in P2 is due to P2 (RMU) incurs the highest costs in processing unhusked rice into rice compared to traders who only sell without processing. Based on share of prices and share of costs, Channel V is considered efficient.

Even though the highest share of prices and share of costs are in farmers and P2, the highest share of profits is in P5 (retailers) of 25.45\%. P5 gains the highest profits because retailers have a small cost, the possibility to sell rice with a long shelf-life, and smaller rice packages sold compared to wholesalers. Furthermore, the highest $\pi / \mathrm{C}$ ratio is in $\mathrm{P} 4$ because P4 incurs the least share of costs. The $\pi / C$ Ratio of P4 is 499 , meaning every IDR 1,incurred by P4 will gain a profit of 499 .

In Channel VI of the unhusked rice/rice distribution, the highest share of prices is in producers/farmers of $34.8 \%$. It is because farmers incur the highest farming costs to produce unhusked rice/rice compared to P1 (farmers' group's association), P2 (RMU), P3 (wholesalers), P4 (bulog), and P5 (bulogmart). Share of costs incurred by producers/farmers is $67.7 \%$. When compared between $\mathrm{P} 1, \mathrm{P} 2, \mathrm{P} 3, \mathrm{P} 4$, and $\mathrm{P} 5$, the highest share of prices and share of margins are in P2 (RMU). Share of margins and share of costs in P2 are $45.3 \%$ and $17 \%$, respectively. The high share of margins and share of costs in P2 is due to P2 (RMU) incurs the highest costs in processing unhusked rice into rice compared to traders who only sell without processing. Based on share of prices and share of costs, Channel VI is considered efficient.

Table 6 - Calculation of Shares of Unhusked Rice/Rice in Channel VI

\begin{tabular}{|c|c|c|c|c|c|c|c|c|c|}
\hline \multirow{2}{*}{ Subject } & \multirow{2}{*}{ Price } & \multirow{2}{*}{ Margin } & \multirow{2}{*}{ Cost } & \multirow{2}{*}{ Profit } & \multicolumn{4}{|c|}{ Share } & \multirow{2}{*}{ п/C Ratio } \\
\hline & & & & & Price (\%) & Margin (\%) & Cost (\%) & Profit (\%) & \\
\hline Producer & 4,200 & & 2,164 & 1,836 & 34.8 & & 67.7 & 4.2 & 1.8 \\
\hline P1 & 4,800 & 600 & 120 & 4,480 & 5.2 & 8.0 & 3.8 & 10.2 & 37.3 \\
\hline $\mathrm{P} 2$ & 8,800 & 3,400 & 570 & 7,430 & 29.6 & 45.3 & 17.8 & 16.9 & 13.0 \\
\hline P3 & 10,500 & 1,000 & 80 & 8,920 & 8.7 & 13.3 & 2.5 & 20.3 & 111.5 \\
\hline $\mathrm{P} 4$ & 11,500 & 1,000 & 80 & 9,920 & 8.7 & 13.3 & 2.5 & 22.6 & 124.0 \\
\hline P5 & - & 1,500 & 180 & 11,320 & 13.0 & 20.0 & 5.6 & 25.8 & - \\
\hline
\end{tabular}

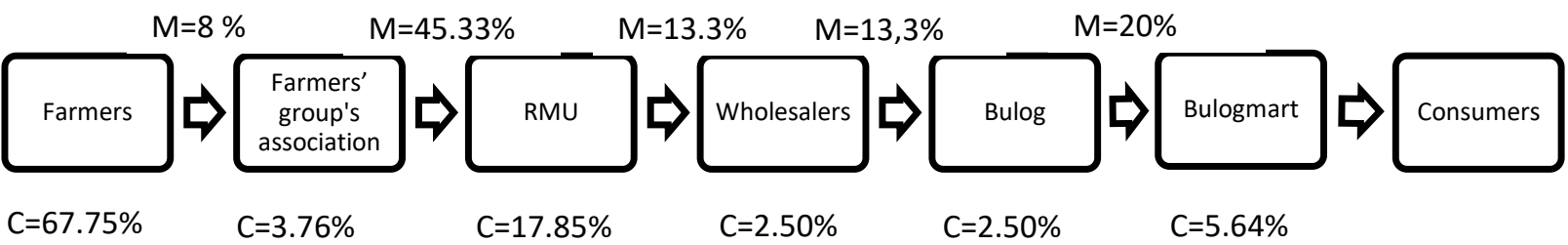

Where: $C=$ Share of costs; $M=$ Share of margins.

Figure 6 - Share of Margins and Share of Costs of Unhusked Rice in Channel VI

Even though the highest share of prices and share of costs are in farmers and P2, the highest share of profits is in P5 (bulogmart) of 25.8\%. P5 gains the highest profits because P5 (bulogmart) has a high margin with a small cost, the possibility to sell rice with a long shelf-life, and smaller rice packages sold compared to wholesalers. Furthermore, the highest $\pi / C$ ratio is in P4 (bulog) because P4 incurs the least share of costs. The $\pi / C$ Ratio of P4 is 124, meaning every IDR 1,- incurred by P4 will gain a profit of 124 . 
In Channel VII of the unhusked rice/rice distribution, the highest share of prices is in producers/farmers of $41.7 \%$. It is because farmers incur the highest farming costs to produce unhusked rice/rice compared to P1 (farmers' group's association), P2 (wholesalers), and P3 (bulogmart). Share of costs incurred by producers/farmers is $69.7 \%$. When compared between P1, P2, and P3, the highest share of prices is in P2 (wholesalers) with the least share of costs. Share of margins and share of costs in P2 are $44.8 \%$ and $5.2 \%$, respectively. It indicates inefficient distribution channels in Channel VII.

The highest share of profits is in P3 (bulogmart) of $36.3 \%$. P3 gains the highest profits because P3 (bulogmart) has a low share of prices, the possibility to sell rice with a long shelflife, and smaller rice packages sold compared to wholesalers. Furthermore, the highest $\pi / C$ ratio is in P2 of 62.9, meaning every IDR 1,- incurred by P4 will gain a profit of 62.9.

Table 7 - Calculation of Shares of Unhusked Rice/Rice in Channel VII

\begin{tabular}{|c|c|c|c|c|c|c|c|c|c|}
\hline \multirow{2}{*}{ Subject } & \multirow{2}{*}{ Price } & \multirow{2}{*}{ Margin } & \multirow{2}{*}{ Cost } & \multirow{2}{*}{ Profit } & \multicolumn{4}{|c|}{ Share } & \multirow{2}{*}{ п/C Ratio } \\
\hline & & & & & Price (\%) & Margin (\%) & Cost (\%) & Profit (\%) & \\
\hline Producer & 2,164 & & 2,164 & 2,636 & 41.7 & & 69.7 & 8.5 & 2.2 \\
\hline $\mathrm{P} 1$ & 7,500 & 2,700 & 600 & 6,900 & 23.5 & 40.3 & 19.3 & 22.1 & 11.5 \\
\hline P2 & 10,500 & 3,000 & 160 & 10,340 & 26.1 & 44.8 & 5.2 & 33.1 & 64.6 \\
\hline P3 & 11,500 & 1,000 & 180 & 11,320 & 8.7 & 14.9 & 5.8 & 36.3 & 62.9 \\
\hline
\end{tabular}

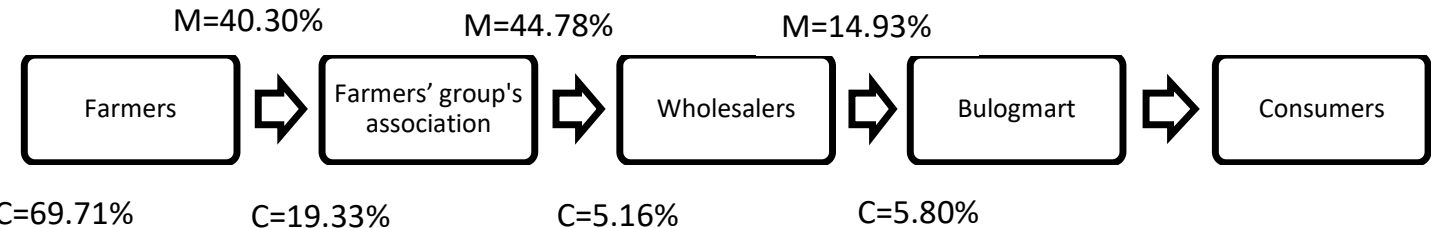

Where: $C=$ Share of costs; $M=$ Share of margins.

Figure 7 - Share of Margins and Share of Costs of Unhusked Rice in Channel VII

In Channel VIII of the unhusked rice/rice distribution, the highest share of prices is in P1 (farmers' group's association) of $41.16 \%$, while the highest share of costs is in farmers. The highest share of margins is in P1 (farmers' group's association). P2 gains the highest share of profits because P2 has a low share of costs, the possibility to sell rice with a long shelf-life, and smaller rice packages sold compared to wholesalers. Furthermore, the highest $\pi / C$ ratio is in $P 2$ because $P 2$ incurs the least share of costs. The $\pi / C$ Ratio of $P 2$ is $49.0 \%$, meaning every IDR 1,- incurred by P4 will gain a profit of 49.0 .

Table 8 - Calculation of Shares of Unhusked Rice/Rice in Channel VIII

\begin{tabular}{|c|c|c|c|c|c|c|c|c|c|}
\hline \multirow{2}{*}{ Subject } & \multirow{2}{*}{ Price } & \multirow{2}{*}{ Margin } & \multirow{2}{*}{ Cost } & \multirow{2}{*}{ Profit } & \multicolumn{4}{|c|}{ Share } & \multirow{2}{*}{$\pi / C$ Ratio } \\
\hline & & & & & Price (\%) & Margin (\%) & Cost (\%) & Profit (\%) & \\
\hline Producer & 2,164 & & 2,164 & 2,636 & 53.3 & & 73.5 & 13.6 & 2.2 \\
\hline P1 & 8,500 & 3,700 & 600 & 88 & 41.1 & 88.1 & 20.4 & 40.8 & 13.2 \\
\hline P2 & 9,000 & 500 & 180 & 7,900 & 5.6 & 11.9 & 6.1 & 45.6 & 49.0 \\
\hline
\end{tabular}

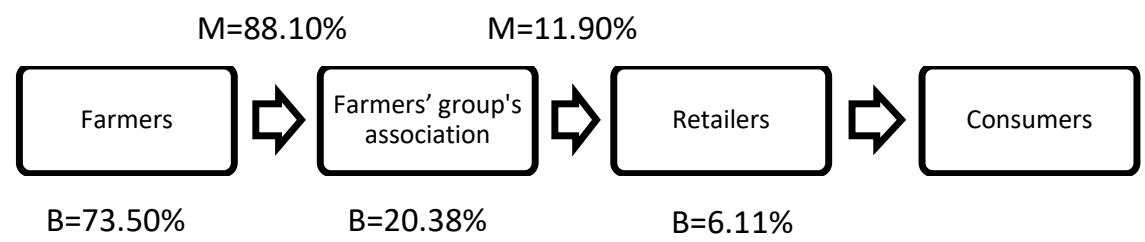

Figure 8 - Share of Margins and Share of Costs of Unhusked Rice in Channel VIII

In Channel IX of the unhusked rice/rice distribution, the highest share of prices is in producers/farmers of $44.8 \%$. It is because farmers incur the highest farming costs to produce unhusked rice/rice compared to P1 (farmers' group's association), P2 (middlemen), and P3 (retailers). Share of costs incurred by producers/farmers is $70.6 \%$. When compared between 
$\mathrm{P} 1, \mathrm{P} 2$, and $\mathrm{P} 3$, the highest share of prices and share of margins are in $\mathrm{P} 1$ (farmers' group's association). Share of margins and share of costs in $\mathrm{P} 1$ are $65.5 \%$ and $19.6 \%$, respectively. Thus, Channel IX is considered efficient.

Table 9 - Calculation of Shares of Unhusked Rice/Rice in Channel IX

\begin{tabular}{|c|c|c|c|c|c|c|c|c|c|}
\hline \multirow{2}{*}{ Subject } & \multirow{2}{*}{ Price } & \multirow{2}{*}{ Margin } & \multirow{2}{*}{ Cost } & \multirow{2}{*}{ Profit } & \multicolumn{4}{|c|}{ Share } & \multirow{2}{*}{$\pi / C$ Ratio } \\
\hline & & & & & Price (\%) & Margin (\%) & Cost (\%) & Profit (\%) & \\
\hline Producer & 2,164 & & 2,164 & 2,536 & 44.8 & & 70.6 & 8.6 & 2.2 \\
\hline P1 & 8,500 & 3,800 & 600 & 2,440 & 36.2 & 65.5 & 19.6 & 26.7 & 13.2 \\
\hline $\mathrm{P} 2$ & 9,000 & 500 & 120 & 8,880 & 4.8 & 8.6 & 3.9 & 30.0 & 74.0 \\
\hline P3 & 10,500 & 1,500 & 180 & 10,320 & 14.3 & 25.9 & 5.9 & 34.8 & 64.6 \\
\hline
\end{tabular}

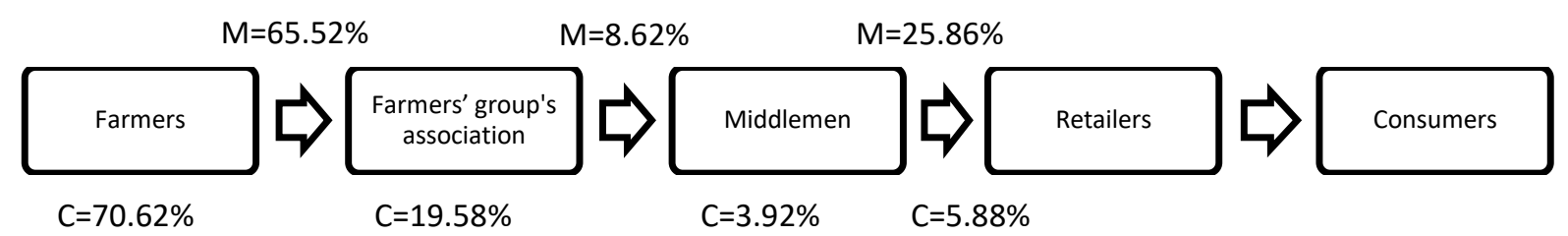

Where: $C=$ Share of costs; $M=$ Share of margins.

Figure 9 - Share of Margins and Share of Costs of Unhusked Rice in Channel IX

Even though the highest share of prices and share of costs are in farmers and $P 1$, the highest share of profits is in P3 (retailer) of 34.8\%. P3 gains the highest profits because P3 (retailer) has a low share of costs, the possibility to sell rice with a long shelf-life, and smaller rice packages sold compared to wholesalers. Furthermore, the highest $\pi / C$ ratio is in $P 2$ of 74.0, meaning every IDR 1,- incurred by P2 will gain a profit of 74.0.

\section{CONCLUSION}

Based on the research results, it can be concluded that Ngawi Regency has nine rice distribution channels. Of the nine channels, six channels of channels I, II, V, VI, VIII, and IX are efficient, while channels II, IV and VII are not yet efficient. It is due to an uneven comparison between share of profits and marketing costs of each marketing agency involved in the marketing process. It implies the need for policies that can mediate the relationship between farmers, all marketing agencies, and consumers in an efficient supply chain and provide reasonable profits for each party.

\section{REFERENCES}

1. Eldabi, T., \& Keramati, A. 2011. System Dynamics in Integration of Supply Chain Management. Lecture Notes in Business Information Processing Volume 88 ,pp. 35-44.

2. Garside, Annisa Kesy and Hasyim Yusuf Asjari. 2015. Simulation of Availability of Rice in East Java. Jurnal Ilmiah Teknik Industri 14(1):47-58.

3. Mardianto, Sudi. 2016. Dynamics of the Marketing Pattern of Grain and Rice in Indonesia. Forum Penelitian Agro Ekonomi 23(2):116-31.

4. Masyrofie. 1994. Dictation of Marketing of Agricultural Products. Sosial Ekonomi Pertanian Universitas Brawijaya Malang.

5. Nee A., Y., H. 2008. Supply Chain Model For Rice In Malaysia - Basics And Challenges. ECER Regional Conference 2008.

6. Sharma V. 2013. Supply Chain management of Rice In India: A Rice Processing Company's Perspective. Int. J. of Managing Value and Supply Chains. Vol. 4, No. 1.

7. South, 2017. Analysis of Network Design of Rice Commodity Supply Chain in Karondoran Village, East Langowan District. Jurnal EMBA 5(2):511-20.

8. Sugiyanto C., 2006. Rice Demand in Indonesia: Revisited. Jurnal Ekonomi dan Bisnis Indonesi. 21(2): 138 - 155 Tomek Wg and Robinson KI. 1990. Cornell University Press.

9. Yosefanny, 2017. Rice Supply Chain Management in South Kotamobagu District, Kotamobagu City. 13:225-38. 